\title{
Tooth Malformation
}

National Cancer Institute

\section{Source}

National Cancer Institute. Tooth Malformation. NCI Thesaurus. Code C118306.

Any abnormality in the growth or formation of one or more teeth. 